\title{
GENDER AND LABOUR IN POST-WAR COMMUNIST POLAND: FEMALE UNEMPLOYMENT 1945-1970
}

\begin{abstract}
The article discusses the issue of female unemployment in Poland between 1945 and 1970 - the scale and reasons of the phenomenon and the attempts to eliminate it. The joblessness history is a pretext for showing the role of gender in the shaping of the labour market in the People's Republic of Poland. The general reason behind the difficulties faced by women in finding a job was that gainful employment, or career, was in the case of females perceived as secondary, and less productive. Women were to perform certain roles in the family, and there was a prevalent conviction that a number of jobs were inappropriate or inadequate for women.
\end{abstract}

Keywords: female work, female unemployment, gender, People's Republic of Poland [PRL]

\section{I INTRODUCTION}

In post-war Poland, two separate queues waited to be served at employment offices: men's and women's, the latter usually being much longer than the former. ${ }^{1}$ While a man would be offered a job rather soon, a woman would often go empty-handed. This was so in 1947 as well as ten years later, and twenty years later again. What does this situation in the labour market of the communist Poland tell us about labour and gender in the People's Republic of Poland (PRL)?

I consider in this article the post-war joblessness among women: what it was like, what were the reasons, and how the state tackled the problem in the years 1945-70. It is through the prism of this

${ }^{1}$ For the metaphor of queue, reflecting social inequalities in shortage circumstances, see Małgorzata Mazurek, Społeczeństwo kolejki. O doświadczeniach niedoboru 1945-1989 (W Krainie PRL, Warsaw, 2010), 18-19. 
phenomenon, which marked its lasting imprint, with an interval in the earliest 1950s, that I intend to show how gender influenced employment and careers in the communist Poland. ${ }^{2}$ The cultural definitions of gender left an imprint on the accessibility of labour and individual jobs, and shaped one of the basic inequalities in the labour market. In spite of the officially existing ideology of equality of the sexes, even Stalinism did not go as far as abolishing the division of labour with regard to gender. The officially propagated 'equal rights' phrases often did not translate into the politics implemented in practice; moreover, they were far from the ideas or concepts of the roles of men and women prevalent in the society.

The scale of unemployment in Poland after WWII was incomparable with that of the interwar period. ${ }^{3}$ It might have affected several dozen or, in some periods, several hundred thousand people - but never millions of them. However, the memory of the pre-war unemployment caused fear of loss of job, particularly in the moments of crisis. On the other hand, in the authorities' view, complete employment was a constitutive element of the economic and social system; deficits in labour and the related negative public feelings or attitudes were a matter of concern. Therefore, although statistically not quite considerable, unemployment did pose a political problem.

Regardless of the period, unemployment in post-war Poland was primarily the problem of women. ${ }^{4}$ Its major features and causes

${ }^{2}$ To date, the issues of gender and female careers in post-war Poland have been discussed the most extensively by Małgorzata Fidelis in her book on women workers, Women, Communism, and Industrialization in Postwar Poland 1945-1956 (Cambridge, 2010). I define 'gender' after J. W. Scott, namely: "Gender is a constitutive element of social relationships based on perceived differences between the sexes, and gender is a primary way of signifying relationships of power." See Joan Wallach Scott, 'Gender: A Useful Category of Historical Analysis', American Historical Review, xci, 5 (1986), 1066-8.

${ }^{3}$ For the purpose of this article I define unemployed people as those who, in spite of several efforts taken, have failed to find a job. When referring to the unemployed, the documents quoted herein mean persons recorded as looking for a job or those who unsuccessfully seek employment without getting recorded as they would not trust the efficiency of employment offices.

${ }^{4}$ For more on female joblessness, see Dariusz Jarosz, 'Kobiety a praca zawodowa w Polsce w latach 1944-1956 (główne problemy w świetle nowych badań źródłowych)', in Anna Żarnowska and Andrzej Szwarc (eds.), Kobieta i praca. Wiek XIX i XX (Warsaw, 2000), 218-23. 
remained basically unchanged. Considerable shortages in job offers for women appeared in 1945-9. Subsequently, in the Six-Year Plan period (particularly in 1950-3), jobs became easily accessible, also for females. Yet, as soon as in 1954, joblessness reappeared and became increasing over the subsequent years. In spite of the efforts made by the state to alleviate the phenomenon, it did not recede throughout the rule of Władysław Gomułka (1956-70). Unemployment among women disappeared again in the early 1970s, a result of the overall rise in demand for jobs and a rather efficient social policy. The state spent substantial sums on creating 'female' jobs as well as on increased family allowances and unemployment benefits. Part-time employment opportunities increased. Unpaid maternity leaves were enjoyed by more than 100,000 female workers per annum. ${ }^{5}$

\section{II \\ STATISTICS AND PROPORTIONS}

It cannot be determined precisely how big was the female population affected by joblessness. The situation was easily perceptible immediately after the war and in the latter half of the 1950s. "All the institutions and offices are sounding the alarm because of the unemployment among women", a female communist activist said at a meeting of the Polish Workers' Party's (PPR) Women's Section in 1947.6 The issue was a serious one still in 1949, judging by reports on the letters received by the popular women's magazine Przyjaciótka:

In the light of the letters about the long and inconclusive search for work in cities (unskilled female workers), letters in which the readers request for being assigned a job, the issue of unemployment amongst women emerges

${ }^{5}$ Warsaw, Archiwum Akt Nowych (hereinafter: AAN), Ogólnopolski Komitet FJN (hereinafter: OK FJN), 978, Informacja o realizacji postanowień VI Zjazdu PZPR i I Krajowej Konferencji PZPR w zakresie poprawy sytuacji kobiet pracujących [Information on the fulfilment of the decisions of the 6th Convention of the PZPR (Polish United Workers' Party) and the 1st National Conference of the PZPR concerning the improvement of the situation of working women].

${ }^{6}$ AAN, Komitet Centralny Polskiej Partii Robotniczej (hereinafter: KC PPR), 295/XVI-2, Protokół z posiedzenia Wydziału Kobiecego KC PPR z dnia 1 lutego 1947 [Minutes of the meeting of the Women's Section of the Central Committee of the PPR, 1 Feb. 1947], p. 27. 
- widows with children, wives of low-salaried workers. There have been numerous signals of long-lasting fruitless search for jobs via employment offices and the related complaining about the system of backings, and about no possibility to get a job without a [communist] Party card. ${ }^{7}$

Similarly, in 1956 as many as 60 per cent of Przyjaciótka readers' letters, of which the weekly received a thousand per day at the time, dealt with problems in finding a job. ${ }^{8}$

The number of women looking for jobs in the second half of the 1940s ranged from 40,000 to $80,000 .{ }^{9}$ This statistics was considered far from the real, though: the Katowice employment office estimated the actual number of jobseekers as tenfold higher than officially announced. ${ }^{10}$ Again, it was assessed in the latter half of the $1950 \mathrm{~s}$ that the number of women looking for a job was a few times higher than those recorded. Some seekers would not get registered at all, others ceased reporting at some point, having lost their hope for finding a job. ${ }^{11}$

Some state that the official jobseeker numbers should be multiplied by six; in Ostrów Maz[owiecka] there are sixty jobseekers recorded, whereas the

${ }^{7}$ AAN, Komitet Centralny Polskiej Zjednoczonej Partii Robotniczej (hereinafter: KC PZPR), 237/XV-31, Listy do Redakcji "Przyjaciółki”. Sprawozdanie na dzień 21 stycznia 1949 [Letters to the Editorial Team of Przyjaciótka. Report as at 21 Jan. 1949], pp. 6-7. As a side remark, the will to get a job became an important reason for joining the communist Party in that period. See Natalia Jarska, 'Frauen in der polnischen kommunistischen Partei - die Paradoxe der Frauenpolitik 1945-1960', Jahrbuch für historische Kommunismusforschung, 2015 [forthcoming].

${ }^{8}$ AAN, Ministerstwo Pracy i Opieki Społecznej (hereinafter: MPiOS), 42, Notatka dla kolegium w sprawie zatrudnienia kobiet [Note to the Board re. employment of women], p. 41.

${ }^{9}$ AAN, KC PZPR, 237/XV-5, Sprawozdanie Wydziału Kobiecego z dnia 2 kwietnia 1949 [Report of the Women's Section of 2 April 1949], p. 28.

${ }^{10}$ AAN, MPiOS, 578, Sprawozdanie z odbytej odprawy Kierowników Oddziałów Urzędów Zatrudnienia w Katowicach [Report on the briefing of the Section Heads at Employment Offices in Katowice], 14 Jan. 1947, p. 41.

${ }^{11}$ AAN, Państwowa Komisja Planowania Gospodarczego (hereinafter: PKPG), 3282, Notatka dla Towarzysza Ministra w sprawie zatrudnienia nadwyżek kobiet [Note to the Comrade Minister re. employment of surplus female workers], 8 Dec. 1955, p. 113; AAN, MPiOS, 923, Zestawienie stanu lokalnych nadwyżek kobiet w 1955 r. [Breakdown of the statistics of local surpluses of women, 1955]; AAN, MPiOS, 42, Notatka dla kolegium, p. 40. 
M[unicipal] C[ommittee] Secretary says that there are 2,000; in Przemyśl, there are approximately 200 registered, whilst a [local female] MP at the Sejm [session] said about some $10,000 .^{12}$

In fact, therefore, the actual scale of unemployment remained unknown.

Right after the war, women accounted for most of the jobseekers: 60 to 70 per cent. ${ }^{13}$ This prevalence was among unskilled workers as well as white collars. ${ }^{14}$ In 1954, almost all Polish jobless were women; there were 152 female candidates per 100 jobs offered, while every male seeker had two job offers to choose, as a countrywide average. ${ }^{15}$ As of January 1967, unemployed women amounted to as many as 90 per cent registered with employment agencies. ${ }^{16}$ Men continued to be offered many more jobs than women; in 1947, jobs offered to seekers formed less than 29 per cent of vacancies reported. ${ }^{17}$ In periods of acute exacerbation of unemployment, this proportion fared even worse. In the spring of 1957, as many as 50 per cent of towns (in eastern, central and southern voivodeships) monitored by the Ministry of Labour and Social Care (MPiOS) offered no vacancies for women at all. ${ }^{18}$ Thus, one queue moved forward fast whilst the other stood still. For instance, in 1947, two and a half more men than women received a job. ${ }^{19}$ The demand for male work much exceeded the number of male jobseekers, whereas the trend was reverse for women. This constituted the basic disproportion in Polish labour market throughout the period under

${ }^{12}$ AAN, MPiOS, 42, Notatka stenograficzna z posiedzenia Kolegium MPiOS w dniu 21 czerwca 1956 [Stenographic note re. the meeting of the MPiOS Board of 21 June 1956], p. 67.

${ }^{13}$ AAN, MPiOS, 562, Zatrudnienie [Employment], p. 65.

${ }^{14}$ AAN, MPiOS, 571, Table [Jobseekers by profession, voivodeship and sex], p. 3.

${ }^{15}$ AAN, PKPG, 3228, Untitled [table showing employment/unemployment statistics, 1950 \& 1954), p. 2.

${ }^{16}$ AAN, OK FJN, 953, Informacja o aktualnej sytuacji w zakresie szkolenia zawodowego dziewcząt i najbliższych zadaniach $\mathrm{w}$ tym zakresie [Information on the present situation in vocational training of young females and the related forthcoming tasks].

17 Rocznik Statystyczny 1948 (Warsaw, 1949), 171-3.

18 Wojciech Daszkiewicz, 'Uwagi o problemie zatrudnienia', Nowe Drogi, 11 (1957), no. 6 , p. 80 .

${ }_{19}$ The proportion is calculated based on: Rocznik Statystyczny 1948, 171-3. 
discussion. Vacancies for women were filled much faster than those devised for men. ${ }^{20}$

This state of affairs indirectly resulted from the fact that the employers specified the sex of their searched-for workers. The workforce acquisition system, even under Stalinism, was not unconcerned about the employee's sex. To give an example, the claimants in Cracow's Employment Department were categorised into four groups: (i) white-collar, male and female; (ii) skilled, male; (iii) skilled/ unskilled, female; and (iv) unskilled, male - workmen. ${ }^{21}$ Access to certain professions was restricted by the law - specifically, by the Women Workers' and Minors' Labour Protection Act of 1924, as amended in 1951, and its related 'forbidden jobs ordinance'; still, the categorisation into 'female'/'male' types of job ensued not only from those special provisions. In any case, gender was an essential criterion, at least no less important than the actual professional or vocational qualifications. Women tended moreover to be less willingly employed. Sections heads and staffing decision-makers admitted that this ensued from the special privileges of working women (maternity leaves, labour protection regulations). As a Party functionary complained,

the directors often see men [as fit] for the job. It so happens that [of] 40 per cent of [employed women], 9 per cent are pregnant. This is the trouble the workplaces fear. Do they say this[?] - no, but they do think it. This [is] not a socialist approach. ${ }^{22}$

Such reluctance was heavily based on unproved or false ideas, and on the fact that women were primarily perceived in the context of their family situation - the thread I will dwell on in more detail below.

${ }^{20}$ Lech Sobczak, Rynek pracy $w$ Polsce Ludowej w latach 1950-1965 (Warsaw, 1967), 68, 106.

${ }^{21}$ AAN, Najwyższa Izba Kontroli, 1319, Protokół z kontroli planowej Samodzielnego Oddziału Zatrudnienia Prezydium WRN w Krakowie [Record of the scheduled inspection of the Autonomous Employment Section, Presidium of the Provincial National Council in Cracow], 8 Nov. 1952, p. 140; Protokół z kontroli Prezydium PRN - Samodzielnego Referatu Zatrudnienia w Łomży [Record of the inspection of the Presidium of County National Council - Autonomous Employment Section], Oct. 1952, p. 196.

${ }^{22}$ AAN, KC PZPR, 237/XV-12, Protokół z narady roboczej w sprawie koordynacji planu zatrudnienia kobiet i placówek socjalnych na 3 rok Planu 6-letniego [Minutes of the working meeting re. coordination of female employment and social establishments for Year 3 of the Six-Year Plan], 21 March 1952, p. 7. 
Finally, owing to the assumed type of economic development, there was always less 'female' work available. Figuratively speaking, a coalminer was always more in demand than a shop assistant. Meanwhile, the borderline between the female and male spheres of employment was shifting very slowly.

\section{III}

\section{EARLY AFTER THE WAR: THE SITUATION OF WIDOWS}

There were peculiar reasons behind the unemployment of females, and they were of various types: economic, social, or cultural. Women's joblessness in communist Poland is a phenomenon in analysing which it is hard to disentangle the network of a number of mutually interrelated factors. For instance, one reason for the unemployment in the years 1955-8 was the centrally managed reductions in the employment, caused by the economic situation; in practice, women were particularly affected, due to the growing criticism of the politics of their mass vocational mobilisation. While these latter reasons can be described as ideology-laden, they had a substantial cultural component to them. I will try, in the following analysis, to trace the 'objective' circumstances of the women's problems with finding a job in the specified years, as well as their connection with the reasons imminent in the existing gender stereotypes. The definitions of femininity and the conviction regarding the social, or public, roles of women and men contributed to the permanently worse position of women in the labour market.

The increase in unemployment among women in the first post-war years stemmed from the war and the occupation. Already during the war, a large group of women forced to seek gainful employment appeared in the labour market. While war normally implies increased economic mobilisation of women, the war and occupation of 1939-45 moreover yielded more male than female casualties. "We are a country of hundreds of thousands of widows and orphans", a (female) PPR activist said in a 1947 Women's Day address. ${ }^{23}$ Immediately after the war, the sex proportions, particularly in urban areas, were considerably disturbed. In 1946, out of the total population of 23.9 million, there

${ }^{23}$ AAN, KC PPR, 295/XVI-27, Przemówienie na 8 Marca [An 8th of March address], p. 34. 
were less than 13 million (54.2\%) women; of the total urban population, 7.45 million, female inhabitants accounted for 56.7 per cent. In the largest cities, the preponderance was 109 to 142 per 100 males. $^{24}$ In 1950, almost every second woman aged 20-49 was 'single' (whereas in 1931, unmarried women had amounted to $34 \%$ ). ${ }^{25}$ The Ministry of Education's estimate said that some 1.5 million 'breadwinners' had been killed during the war. ${ }^{26}$ They had to be replaced in their role by someone else - a woman, in most cases. Apart from providing for themselves - a frequent situation before the war as well - they now had to subsist their children. There reportedly were some 200,000 widows burdened with infants. ${ }^{27}$ Divorced women, whose situation often resulted from long-lasting wartime separation, shared this lot.

In the post-war conditions, it was not always possible to continue the gainful activity undertaken during the occupation:

The economic stability (shrinkage of non-regulated commerce and stockouts, among other factors) launched to the labour market subsequent large groups of women, mostly unqualified: widows and those abandoned by the until-then family supporters, who had 'managed it somehow' in the war circumstances. ${ }^{28}$

The 'shrinkage of non-regulated commerce' can be considered an euphemism: in fact, the state gradually destroyed any forms of private entrepreneurship, depriving hosts of women of opportunities to earn

${ }^{24}$ Rocznik Statystyczny 1947 (Warsaw, 1948), 19, 27. The 1931 statistics say that $53 \%$ of urban inhabitants were female. See also Dariusz Jarosz, Polacy a stalinizm 1948-1956 (Warsaw, 2000), 120.

${ }^{25}$ Małgorzata Fidelis, 'Czy nowy matriarchat? Kobiety bez mężczyzn w Polsce po drugiej wojnie światowej’, in Anna Żarnowska and Andrzej Szwarc (eds.), Kobieta $i$ rewolucja obyczajowa: społeczno-kulturowe aspekty seksualności. Wiek XIX $i$ XX (Warsaw, 2006), 426.

${ }^{26}$ Jacek Kulbaka, 'Matka, dziecko i rodzina w zasobach archiwalnych Archiwum Akt Nowych w Warszawie $z$ pierwszych lat po II wojnie światowej', in Krzysztof Jakubiak (ed.), Partnerka, matka, opiekunka. Status kobiety $w$ dziejach nowożytnych od XVI do XX wieku (Bydgoszcz, 2000), 197.

${ }^{27}$ AAN, Ministerstwo Zdrowia, 121, Materiały uzasadniające konieczność przedłużenia pomocy zagranicznej dla Polski na rok 1947 [Materials giving grounds for the need to extend foreign assistance for Poland to the year 1947], p. 4.

${ }^{28}$ AAN, KC PPR, 295/XVI-17, Irena Bobrowska, 'Aktywizacja kobiet' [Mobilising the activity of women] [no date specified], p. 77. 
a living. There also functioned an enormous black market, whose development and operation during the war had markedly been contributed to by women. Estimates have it that illegal commercial dealings and unlicensed labour continued to be practiced by approximately 600,000 women after the war. ${ }^{29}$

Experts opined that joblessness of women was strictly connected with their single status and loss of sources of subsistence. Yet, this view was stereotypical, to a degree. Women unsuccessfully looking for a job were indeed 'the sole breadwinners'. In Poznań area, single, usually young and completely unskilled, women formed 70 per cent of this population..$^{30}$ However, not only single women, unexpectedly deprived of subsistence, were in search for jobs. Przyjaciótka received letters also from married women willing to make some extra money added to their husbands' salaries. ${ }^{31}$ A large group of female seekers came from pauperised families. As the head of Warsaw's Employment Office noticed in autumn 1946:

The unemployed women are, for the most part, individuals who before the war ran their households, with their husbands or children as the breadwinners, or made a living on the interest from their small caps and realties. The war took the means of subsistence away from them, and forced them to work. ${ }^{32}$

Pauperisation and property transformations contributed to increasing ranks of women in need of employment. Some would be forced to take a job by poverty caused by loss of property, or low earnings of the main breadwinner. The comparison of salaries before and after the war tells us that they went down remarkably. As Jędrzej Chumiński says, " 44.5 per cent of families covered by research did not reach the

${ }^{29}$ Jędrzej Chumiński, Ruch zawodowy $w$ Polsce $w$ warunkach kształtującego się systemu totalitarnego 1944-1956 (Wrocław, 1999), 86. On illegal trade after WWII, see Jerzy Kochanowski, Tylnymi drzwiami. “Czarny rynek” w Polsce 1944-1989 (Warsaw, 2010).

${ }^{30}$ Marcin Zaremba, Wielka Trwoga. Polska 1944-1947. Ludowa reakcja na kryzys (Cracow and Warsaw, 2012), 239.

${ }^{31}$ AAN, KC PZPR, 237/XV-31, Listy czytelników do Redakcji [“Przyjaciółki”]. Sprawozdanie za okres sześciotygodniowy [Letters from readers to the Editorial Team (of Przyjaciótka). Report as for a six-week period], 1 April 1949, p. 66.

32 AAN, MPiOS, 570, Stan zatrudnienia ludności Warszawy [Employment statistics of the population of Warsaw], p. 1. 
minimum subsistence income defined in the late 1946 by the Joint Committee for Wages and Salaries as 6,000 złoty per month."33

In demand of jobs were not only those women who were forced by various circumstances of their lives. According to an industry questionnaire of 1947, one reason for why women looked for jobs was described as having 'become professionally independent' during the war. "In white-collar professions, women having their families and being once their husbands' dependants are now willing to do gainful work regardless of their wealth." 34 Incentives other than economic could have played a significant role in taking a job at least with some professions.

The conviction dominated that lack of relevant skills, or qualifications, was the major obstacle in finding a job. Such was the opinion of communist (PPR) ${ }^{35}$ as well as socialist activists. ${ }^{36}$ This view was, to an extent, stereotypical, not subject to verification: "as is known to everybody, unemployment mainly affects women, as those are, largely, unqualified forces", a (female) labour inspector concluded. ${ }^{37}$

These opinions should be regarded as not fully compliant with the reality, though. A definite majority $(90 \%)$ of jobless women had no qualifications, indeed; ${ }^{38}$ but many men shared this situation. What is more, also skilled women had problems finding a job. ${ }^{39}$ For instance, among Przyjaciótka readers complaining about inability to get employed was "a rather significant percentage of unemployed

${ }^{33}$ Chumiński, Ruch zawodowy, 132-3.

${ }^{34}$ AAN, Centralny Urząd Planowania, 3201, Wyniki ankiety o polityce zatrudnienia na r. 1948 [Results of a questionnaire on the 1948 employment policy], p. 15.

${ }^{35}$ AAN, KC PPR, 295/XVI-2, Protokół z posiedzenia Wydziału Kobiecego, 27.

${ }^{36}$ AAN, Centralny Komitet Wykonawczy Polskiej Partii Socjalistycznej, 235/ XVI-16, Rola kobiet w PPS [The role of women in the Polish Socialist Party], p. 11.

${ }^{37}$ AAN, Komisja Centralna Związków Zawodowych (hereinafter: KCZZ), V/16, Protokół $z$ konferencji inspektorek pracy do spraw kobiet i młodocianych [Record of a conference of labour inspectors for women and the minors], p. 23.

${ }^{38}$ AAN, KC PPR, 295/XVI-2, Produktywizacja kobiet na tle obecnej sytuacji gospodarczej [The productivisation of women against the background of the present economic situation], p. 37. The situation remained unchanged a year later: AAN, MPiOS, 571, Stan bezrobocia w Polsce w I-szym półroczu 1948 r. [Unemployment statistics in Poland in Jan. to June of 1948], p. 7.

${ }^{39}$ E.g., AAN, KC PZPR, 237/XV-31, Redakcja "Przyjaciółki". Sprawozdanie za okres od 17 XI do 1 XI 1949 [Przyjaciótka Editorial Board. Report as for 17 Sept. to 1 Nov. 1949], p. 136. 
seamstresses". ${ }^{40}$ The role of gender in the shaping of unemployed was not appreciated.

In the perception of contemporary people, the impact of the war on women's professional careers was undisputed - but temporary. As Życie Warszawy daily wrote in January 1947:

The last war launched a revolution in the idea about women's labour. Women have namely proved that they can replace men at, virtually, any job position. Several millions of females worked in all branches of industry. ${ }^{41}$

The comments added, in any case, that jobs taken on a mass scale was not interrelated with vocational training and skill development. Furthermore, many popular forms of wage-earning were casual, temporary. The uniqueness of the time of war could rather easily be replaced by a post-war stabilisation and resumption of the old roles. Such developments were rather commonplace in post-war Europe and in the United States, and this is why the gender revolution turned out to be limited. ${ }^{42}$ Many phenomena related to the wartime and post-war demographic situation, such as hiring women for jobs regarded as typical of males, were seen as negative in Poland also, and calling for a change in the longer run. Yet, such change was inhibited by the enormous demographic problem.

The unemployment of women was moreover influenced by the preference for hiring men. Given that the industry was primarily oriented to productivity, performance and delivery of plans, men appeared to be more competitive employees. This is how the reasons

40 Ibidem, Sprawozdanie $z$ analizy listów czytelników za okres od 20 XI do 31 XII 1949 [Report on the analysis of letters from readers, as for 20 Nov. to 31 Dec. 1949], p. 153.

41 'Pół miliona kobiet czeka na przeszkolenie. Bezrobocie na tle Planu Odbudowy’, Życie Warszawy (1947), 7 Jan.

${ }^{42}$ It was frequent that women would be sacked in order to offer the job to men returning from the war; see Claire Duchen, Women's Rights and Women's Lives in France 1944-1968 (London and New York, 1994). This had happened in the revolutionary Russia after WWI as well. See Wendy Z. Goldman, Women at the Gates: Gender and Industry in Stalin's Russia (Cambridge, 2002), 10-11. On careers of women in Europe after WWII, see Francisca de Haan, 'Women as the "Motor of Modern Life”. Women's Work in Europe West and East since 1945', in Joanna Regulska and Bonnie G. Smith (eds.), Women and Gender in Postwar Europe: From Cold War to European Union (New York, 2012), 87-103. 
were identified for which many times a woman was sacked so that a man could replace her. ${ }^{43}$

Hiring or dismissal of a female worker was often dependent on her family situation: widows and 'the only breadwinners' were perceived differently than married women. There was a mine where it was 'commonplace' to fire female workers on the grounds that their husbands had returned from a camp or forced labour. ${ }^{44}$ On the one hand, female activists resented against such conduct which attested to reluctance to employ married women (who were believed to be supported by their husbands); on the other, they would use similar arguments themselves. In Katowice, the Women's Section of the District Committee of Trade Unions (OKZZ) adopted a resolution whereby those married women whose husbands were employed and had no large family to provide for would be dismissed, and replaced by women having dependant children. ${ }^{45}$ As it seems, this was a rather widespread attitude; it was based on the belief that priority in access to jobs should be ensured to single mothers (mostly, widows). While their situation was really hard, such solutions were based on the underlying deeply rooted conviction that women ought to take a job only out of necessity. The letters sent to Przyjaciótka in 1949 concerning unemployment were commented upon thus: "There are cases occurring that employment office clerks completely refuse entering married childless women whose husbands have a job, claiming that such women do not need to work." 46 Employers accepted such reasoning too, and thus, for instance, released some female workers to hire instead "those whose husbands were killed and who have small children to support". ${ }^{47}$ In such a context, labour became, as

${ }^{43}$ AAN, KC PPR, 295/XVI-2, Produktywizacja kobiet, p. 37.

${ }^{44}$ Ibidem, 295/XVI-25, Położenie kobiet w skontrolowanych przedsiębiorstwach w XI 1946 [The situation of women in the inspected enterprises in Nov. 1946], p. 24.

${ }^{45}$ AAN, KCZZ, V/ 62, Sprawozdanie z działalności Wydziału Kobiecego przy OKZZ za VII 1946 [Report on the activities of the Women's Section of the OKZZ as for July 1946], p. 1.

${ }^{46}$ AAN, KC PZPR, 237/XV-31, Listy do Redakcji "Przyjaciółki”. Sprawozdanie za okres dwutygodniowy [Letters to the Editorial Team of Przyjaciótka. Report as for a 14-day period], 28 March 1949, p. 54.

${ }^{47}$ AAN, KCZZ, V/62, Sprawozdanie $z$ działalności Referatu Kobiecego przy OKZZ w Katowicach za X 1946 [Report on the activities of the Women's Section of the OKZZ in Katowice, as for October 1946], p. 16. 
it were, a social benefit and a form of assistance to families whose 'breadwinners' were taken away by the war. As Kobieta Dzisiejsza periodical observed, ${ }^{48}$

today, the right of single mother to gainful work has become, as never before, a historical necessity - in the name of rescuing not only such women but, in the first place, their children. ${ }^{49}$

In the light of the convictions of the time, the right of the other women to work was sometimes challenged.

\section{IV}

STALINISM: UNEMPLOYMENT ENDS, DIVISIONS REMAIN

The consequences of the war impressed a lasting influence on the situation of many women who needed to make a living. The accelerated industrialisation of the country, implemented since 1949 (including the Six-Year Plan of 1950-5), absorbed considerable surpluses of workforce, not limited to female workers. The Party and State decision-makers realised that industrialisation could not be pursued without mass vocational mobilisation of women. Combined with ideologically-motivated slogans of emancipation of women through making them part of production, this requirement resulted in a 'productivisation' of women policy. The instruments of this policy, which strove not only for increased employment but also for a broader participation of women workers in professions deemed 'male' and professional advancement of women, included the propaganda, Party guidelines and administrative measures (determining the compulsory employment rates for females). ${ }^{50}$ In $1950-3$, the female unemployment issue became marginal, compared to the earlier and later years. Local and transitional problems with finding a job did appear, and fear of joblessness certainly did not disappear - but it was much easier to find employment in the time of industrialisation. Women were

${ }^{48}$ Biweekly edited since 1946 by Social-Civic League of Women.

${ }^{49}$ W. Kostecka, 'My też chcemy budować!', Kobieta Dzisiejsza, 4 (1947), 10.

${ }^{50}$ For more on women's employment policy under Stalinism, see Fidelis, Women, Communism; Jarosz, Polacy a stalinizm; Natalia Jarska, 'Praca zawodowa robotnic w Polsce w latach 1945-1960’ [Institute of History, Polish Academy of Sciences, $\mathrm{PhD}$ thesis (typescript)]. 
offered then many jobs normally performed by men. As of 1950, there was an average of 15 females recorded as jobseekers per 100 vacancies, countrywide. ${ }^{51}$ In 1951 and 1952 all the women (544,000 and 543,600 , respectively) who reported to employment sections or departments received a job offer. ${ }^{52}$ In the years $1950-8$ (in practice, until 1957), so-called service orders were moreover in force, covering a total of 417,000 tertiary and secondary vocational school graduates until $1956 .{ }^{53}$ Skilled workers were particularly in demand in the rapid industrialisation process.

The 'productivisation' propaganda proclaimed removal of barriers set by gender in the sphere of professional activities; yet, in practice, the gender-based division continued to be much of relevance. As noted by Małgorzata Fidelis: "When encouraging some women to enter male-dominated occupations, the party-state continued a precommunist tradition of employing the majority of women in work that was gendered female". ${ }^{54}$ The campaign promoting female work in professions described as 'new' was not tantamount to abolished gender division of work. Only certain specified jobs were designed for women. The ideas of women's particular psychophysical predispositions for performing some types of jobs - such as care for details, more disciplined approach, or an emotional relationship with the piece of machinery operated, were still in use. ${ }^{55}$

Also the Stalinist workforce acquisition system did not remain indifferent to employee gender. Establishments usually defined the sex of the employees they hired, or 'ordered for', though sometimes it was remarked that a worker could be 'of either sex'. Any workforce balances, employment and headhunting plans took the gender aspect into account. This was meant to contribute to increased employment among women, whereas the principle, by itself, solidified the gender-related inequalities. Lists of jobseekers and vacancies

${ }^{51}$ AAN, PKPG, 3228, Untitled, 2.

${ }^{52}$ AAN, NIK, 1319, Protokół z kontroli Departamentu Zatrudnienia MPiOS w zakresie werbunku niewykwalifikowanej siły roboczej i pośrednictwa pracy za okres 1952 r. [Report of the inspection carried out by the Employment Department, Ministry of Labour and Social Care as for the year 1952], 20 Dec. 1952, p. 9.

${ }^{53}$ Sobczak, Rynek pracy, 59-60.

${ }^{54}$ Fidelis, Women, Communism, 77.

${ }^{55}$ Ibidem, 145-8. 
were compiled with use of this criterion as well. Propagated in the period 1950-5, equal rights of women in access to labour did not imply the questioning of gender as the criterion applicable to the labour market.

\section{$\mathrm{V}$ \\ DE-STALINISATION AND 'MINOR STABILISATION' \\ IN THE LABOUR MARKET}

As joblessness reappeared in 1954, its reasons were, at first glance, somewhat different compared to those prevalent in the late 1940s. The demand for workforce was gradually decreasing, and mass headhunting came to a stop.

The state settled down to 'putting in order' the employment affairs. Several reductions were discussed and ordered in the years 1955-8. The term officially used was 'eliminate the administrative outgrowths' (or excesses), while redundancies extended not only to white-collars, affecting, in particular, a few employee groups, females included.

The very content of the redundancy instructions or orders issued were discriminatory to women (though not immediately). The resolution of the Council of Ministers of January 1957 'on the rules of dismissal, training and employing workers in connection with the reorganisation of the administration' offered a pretext for sacking married workers:

In case of coequal professional qualifications, in dismissing an employee, the following should be taken into consideration: the employee's family status, age, number of working persons in the family, and whether he or she owns a farm household or another workplace. ${ }^{56}$

These criteria naturally referred also to men, while the 'family status' and 'number of working persons in the family' mostly resolved the question to the detriment of women. Another resolution, of February 1958, specified that

${ }^{56}$ Monitor Polski, 6 (1957), item 37, 'Uchwała w sprawie zasad zwalniania, przeszkalania i zatrudniania pracowników w związku z reorganizacją administracji' [Resolution determining the principles of dismissal, training and employment relative to the administration reorganisation project]. 
when it comes to dismissing an employee, their usefulness with the workplace ought to be taken into account, along with their professional skills, as well as possessing additional sources of subsistence. ${ }^{57}$

This latter provision aimed at working married women. ${ }^{58}$

In fact, employment reduction actions carried out in a number of establishments in 1957-8 became an opportunity for sacking their female workers. ${ }^{59}$ At a 1958 meeting of the Women's Committee, Central Council of Trade Unions (CRZZ), the debaters agreed that in the elimination of excess employment, women were dismissed in the first place. Facts were mentioned of pregnant women, all married women, and skilled workers having to leave the job. ${ }^{60}$ No numerical data are available which would help estimate the scale of this phenomenon; the figures must have certainly been significant. Research carried out in thirteen large enterprises showed that 106 new male workers were offered employment per 100 dismissed, the corresponding ratio for females being 71 to 100 . It was paradoxical that women were sacked as they were considered a more expensive workforce, due to their maternity privileges - while their earnings were continually lower. ${ }^{61}$ The dismissal examples confirm that gender was much relevant, if not crucial, in redundancy actions; instances of removal of highly skilled female workers were not infrequent. ${ }^{62}$ Common to the female workers of various education levels or backgrounds,

${ }^{57}$ Monitor Polski, 16 (1958), item 100, 'Uchwała nr 42 Rady Ministrów z dnia 26 II $1958 \mathrm{w}$ sprawie zadań polityki zatrudnienia w uspołecznionych zakładach pracy' [Resolution no. 42 of the Council of Ministers of 26 Feb. 1958 on the policy tasks related to employment with socialist workplaces].

${ }^{58}$ Małgorzata Mazurek, Socjalistyczny zakład pracy. Porównanie fabrycznej codzienności w PRL i NRD u progu lat sześćdziesiątych (Warsaw, 2005), 265.

${ }^{59}$ E.g., AAN, KC PZPR, 237/VII-3839, Informacja [Information], 11 June 1958, p. 19; Sobczak, Rynek pracy, 174.

60 Warsaw, Archiwum Ruchu Zawodowego (hereinafter: ARZ), Komisja Kobieca Centralnej Rady Związków Zawodowych (hereinafter: KK CRZZ), 103, Protokół plenarnego posiedzenia [KK CRZZ minutes of the Committee's plenary meeting], 27 May 1958.

${ }^{61}$ ARZ, KK CRZZ, 108, Tendencje spadkowe w zatrudnieniu kobiet [Decrease trends in female employment], pp. $24-5.70 \%-80 \%$ jobs offered to women were concentrated in income groups not in excess of $1200 \mathrm{zl} / \mathrm{month}$; see Sobczak, Rynek pracy, 128. The average monthly salary at the time was $1350 \mathrm{zl}$.

${ }^{62}$ Warsaw, Ośrodek Dokumentacji i Zbiorów Programowych Telewizji Polskiej (hereinafter: ODiZP TVP), 1050/22, Biuletyn, 18 (1957), 19 March. 
at different positions, was their being perceived by staff managers as married women and/or mothers whose work was merely an addition to their husbands' careers.

This conviction reinforced the social justice idea: one 'deserved' work due to his or her tough family situation. It was the mentality of the decision-makers - and the popular conviction too - that certain groups of workers were subject to redundancy, also in order to ensure job opportunities to others. Skills, qualifications, or even the worker's usefulness for the enterprise were secondary. The reasoning along the lines of social justice is well illustrated by a fragment of the letter from a member of an office staff to Trybuna Ludu, the communist Party's daily newspaper:

Our office, which employs eighteen white-collar workers, has five ladies whose husbands earn more than 2 thousand [złoty] per month, are prosperous, their kids using kindergarten, whereas other people, burdened with families, are being sacked, while for them dismissal from work is a tragedy. Something is wrong there. ... I talk to the people and we all agree at one point: that if those married women would be dismissed whose husbands' earnings would suffice for a regular decent subsistence - then, it seems to me, the issue of joblessness among women would get significantly diminished. ${ }^{63}$

In 1958, the Public Opinion Polling Centre (OBOP) held a survey that made it apparent that a definite majority of the society $(74.7 \%)$ shared the view that establishments employed excessive staff. The polled indicated the employee groups that, in their opinion, should be dismissed in the first place. 'Wives of high-earning husbands' were pointed by almost a half $(49.2 \%)$ of the respondents; this confirms the evidence, known from other sources, that the belief was widespread. This research's data show, in parallel, that the public was divided in their opinions on this point.

An insight in how social justice was comprehended is also given in the answers to the question: Who ought to be protected against redundancy? The polled first indicated those "for whom dismissal would imply serious family-related consequences" ("specifically,

${ }^{63}$ AAN, KC PZPR, 237/XXV-21, Biuletyn, 8/176 (1957), 82. Dismissals of married women were proposed by Po Prostu weekly readers, some of whom went as far as demanding a ban on employing them. Adam Leszczyński, Sprawy do załatwienia. Listy do "Po Prostu" 1955-1957 (Warsaw, 2000), 119-20. 
securing the family's livelihood"); 'lonely people' came third. Women could have been included in either category. Thus, women were of a different status - conditional upon their marital status, husband's salary, number and age of children. In some circumstances, they were granted primacy in employment; otherwise, they would be 'sent home'.

The attitude towards working women, particularly married ones and mothers, was moreover reflected in the gossips about their dismissals. Those appeared in as early as 1953, long before the first official 'elimination of excesses' took place. ${ }^{64}$ A woman from Tarnowskie Góry wrote:

I have learnt from the foreman that all the married women are due to be sacked from work. I have been into this job for three years now and have got so accustomed to working that I cannot live without it. Besides, my husband is a disabled war veteran. ${ }^{65}$

Information on plans to dismiss married women reappeared in early 1957 in connection with the Council of Minister's redundancy resolution. A woman employed with the Ursus Tractor Factory reported on a 'gossip' that 'married woman with children' will be relieved. ${ }^{66}$ A steelworks' personnel department stated that "relieved shall be all the married women, childless or with one kid, in the event that the husband's and wife's salary is in excess of 520 zł per person". ${ }^{67}$ The hearsay version according to which mothers would lose their jobs was widespread. In Lodz, in autumn 1955, they said "that from 1st January onwards, a new Trade Unions' directive will be in force concerning dismissals of mothers". ${ }^{68}$ Other gossips had it that mothers of several kids will be fired, in exchange for increasing the fathers' family allowance. ${ }^{69} 2.8$ million families, in total, enjoyed such allowances in 1955. The allowance's amount was increased in 1957, by decision of

${ }^{64}$ AAN, Urząd Rady Ministrów, 13/3, Notatka w sprawie głównych problemów występujących w listach i skargach w latach 1951-1953 [Note re. the central issues reported in the letters and complaints in the years 1951-3], 9 April 1954, p. 14. The like hearsays were mentioned in Ministry of Public Security's reporting materials.

65 ODiZP TVP, 1050/9, Biuletyn, 10 (1954), 8 Feb.

${ }^{66}$ Ibidem, 1050/22, Biuletyn, 3 (1957), 5 Jan.; Biuletyn, 11 (1957), 12 Feb.

${ }^{67}$ Ibidem, Biuletyn, 18 (1957), 19 March.

${ }^{68}$ ODiZP TVP, 1050/10, Biuletyn, 49 (1955), 17 Dec., p. 9.

${ }^{69}$ AAN, KC PZPR, 237/VII-3842, Informacja, no. 200/3271, 16 Dec. 1955, p. 76. 
the Politburo of the Central Committee of the Polish United Workers' Party (PZPR), but remained low (200 zł, on average).$^{70}$ Increase of allowances was perceived as a means of restricting the female labour supply. Some reported that "maternity leave is to be cancelled" and nurseries liquidated, or nursery fees considerably increased. ${ }^{71}$

The arguments given by women in their letters, complaining about dismissals or threat of redundancy, seem characteristic. The authors referred to the sense of social justice or, at times, to their own merits related to the workplace; the idea of equal rights was never mentioned. A worker at Cracow's 'V.I. Lenin' Steelworks, threatened by dismissal, pointed in her letter to the fact that she had many children and her husband's salary was low: these were her arguments for her right to do the job, while she spoke against her married workmates:

Our department head declared to us a few times that the women will be all dismissed from work, married women in the first place ... regardless of the number of children. I've got six kids. My husband's wages would absolutely be insufficient for modest clothing and sustenance ... There are many countryside women working in our place, owning properties there. Their husbands work also. They have a life like in paradise. There are misses among them who earn 2,200 zł each. ${ }^{72}$

Hearsays and redundancy actions were set in a broad context of discussions about the legitimacy of mass employment of women and criticism of the 'productivisation' policy. In 1955-6, the wave of criticism encompassed the working and living conditions of female workers; 'the thaw' allowed to openly address the problem of how fictitious the equality slogans might have been when confronted with the reality. Discriminatory practices and low salaries of female workers were noticed; the defeat of the social project meant to release women from their duties related to the roles of mother and housewife was criticised. Many believed that taking up gainful jobs was, in reality, motivated exclusively by economic coercion, rather than being an act

${ }^{70}$ KK CRZZ (ed.), Kobieta w Polsce (Warsaw, 1960).

${ }^{71}$ ODiZP TVP, 1050/10, Biuletyn, 49 (1955), 17 Dec., pp. 9-10; ODiZP TVP, 1050/22, Biuletyn, 3 (1957), 5 Jan.

${ }^{72}$ AAN, KC PZPR, 237/XXV-21, Biuletyn, 8/176 (1957), p. 89-90. Similarly (letter from a woman worker from Zawiercie steelworks): 237/XXV-28, Biuletyn, 16 (1959), 10 Nov., p. 140. 
of emancipation. ${ }^{73}$ Criticised in the press discussions was the equality policy as such - as it, apparently, not only ignored the realities but also marked an outrage at the differences between the sexes, as they were traditionally construed and perceived:

[Gender] equality has often been misunderstood, and applied mechanically, without taking into account woman's lesser physical capacities, her specific physiological properties, her maternity functions and obligations. ${ }^{74}$

'Productivisation' was subjected to criticism as it levelled the gender differences. Thus, labour performed by women, especially in 'male' professions, was perceived as unnatural. Female workers, in particular, became a symbol of immorality which apparently resulted from 'unnatural conduct of women' related to migration and industrialisation. ${ }^{75}$

Journalists and readers touched upon the social consequences of 'productivisation'. Emancipation of women, also by means of their careers, apparently brought about a crisis of morality, family, and private life. The legitimacy of mass vocational mobilisation of women was called into question, saying it was associated with certain (really existing) social pathologies of the Stalinist period. Mothers' labour was apparently one of the reasons of hooliganism. Finally, the difficulties related to the necessity for women to combine the roles of worker, mother and housewife were highlighted. In summary, labour had proved to be a delusory path of women's emancipation, and it had disturbed the social order.

Women's gainful work was construed, primarily, as a consequence of low salaries and the overall standard of life, these being unwelcome circumstances. "Why should all of a family have to work to make a living or survive ([including] mothers of small children and young people)?", an anonymous author of a letter to PZPR's Central Committee asked, in the spring of $1956 .{ }^{76}$ A simple consequence of such ideas was perception of female labour done on no economic grounds as simply irrelevant or, outright, detrimental. As a radio listener put it in

73 'Rozpoczynamy dyskusję o zatrudnieniu kobiet (wypowiedź Marii Jaszczuk)', Kobieta $i$ Życie, 34 (1956), 2.

74 'Jak żyjesz? Czym się interesujesz? Do czego dążysz?', ibidem, 32 (1956), 5.

Por. Fidelis, Women, Communism, 212.

${ }^{75}$ Ibidem, 178-82.

${ }^{76}$ Quoted after: Paweł Machcewicz, Polski rok 1956 (Warsaw, 1993), 73. 
his letter, 'well-to-do' women worked "solely [to earn] for their outfits and out of boredom". ${ }^{77}$ The workers of the truck plant (Fabryka Samochodów Ciężarowych, FSC) in Starachowice, central Poland, believed that, "unless their husbands do not work", married women should be dismissed, as a means to solve the unemployment problem. ${ }^{78}$

Women themselves took varied stances on the issue. A workwoman and failing jobseeker from a locality near Warsaw concluded that:

A woman who has a husband should keep watch over her children and her home, otherwise devils incarnate and no children are growing up, because their mother is [always] rushing to work, incapable of taking care about them the way she should. The husband should earn for his home [i.e. family], then there sure wouldn't be so many women without work. ${ }^{79}$

"Some women write that if the material conditions so allowed, they would be so willing to quit their work and take care of their homes and children only", the editors of Kobieta $i$ Życie women's weekly concluded, based on the letters received from the readers. Women dissatisfied with their careers complained in their letters about their low salaries, overburdening with work (due to having to work overtime), bad workplace relationships, difficulties related to coping with their household duties and acquiring higher qualifications and getting promoted owing to their family determinants. ${ }^{80}$ Burdensomeness and effort involved in running a household were highlighted.

Alongside such aspects, however, contrary views were clearly articulated, pointing to the role of non-material motivations. Many a woman complained about being dismissed for gender-related reasons, with a sense of unfairness. A female Ursus factory worker wrote:

It is a fact that most women approach their employment as a necessary evil; but there are such who have the skills and love for their profession, and are willing to continue to work. ${ }^{81}$

77 ODiZP TVP, 1050/24, Biuletyn, 34 (1958), May, p. 7. Women work 'to primp and preen', as a letter to Po Prostu weekly said; see Leszczyński, Sprawy do załatwienia, 119.

${ }^{78}$ AAN, CRZZ, I/708, Postulaty FSC w Starachowicach [Postulates proposed by the FSC of Starachowice], p. 300.

${ }^{79}$ ODiZP TVP, 1050/9, Biuletyn, 12 (1954), 18 Feb., p. 4.

80 'Jak żyjesz?', 5.

${ }^{81}$ ODiZP TVP, 1050/22, Biuletyn, 3 (1957), 5 Jan., p. 5. 
In protest against redundancies and dismissals, women referred to their ability to combine the roles, thus, as if, facing down the publicly raised childcare issues. ${ }^{82}$ Extra money earned, they argued, is a benefit to the children and family.

Skilled woman workers were also reluctant to quit their jobs; many of them performed 'male' jobs, as was the case with the aforementioned Dąbrowa-Górnicza steelworks workers. Dismissal from their underground work was also protested against by female miners; they were joined by female lorry drivers. ${ }^{83}$ In spring 1957 , the Central Committee of PZPR received a letter signed by fourteen female workers:

On behalf of Silesian woman miners, we should like to address Comr[ade] Gomulka with the question: What is the rationale behind our planned dismissal from our underground work? In the past years, women did their jobs under the ground too, in any case. There are many women among us who have a seven or eight years' underground [work] record. ${ }^{84}$ Now that we have spent our young years doing underground work, we ought not to be dismissed, in our advanced age. ... After all, we have families to support, just like men. Many among us are widowed, or divorced, having children to provide for. And we are also willing to feed our children, dress them, like the miner fathers. We have not taken our hard work of mining under the ground for delight or luxury, but for our lives as well as for our children, to the benefit of our home country ....$^{85}$

The miners referred to the sense of responsibility for their kids and to the right to work because of their being 'the only breadwinners' for their families. They demanded being put on equal footing with male miners who subsisted their families based on their work under the ground. Such work was much more dangerous, but better paid, than working on the ground. The letter's authors characteristically argued that their work would not serve to 'excessively' enhance their material status.

82 Fidelis, Women, Communism, 225.

${ }^{83}$ Ibidem, 219-24. Eadem, 'Equality through Protection: The Politics of Women's Employment in Postwar Poland, 1945-1956', Slavic Review, 63 (2004), no. 2, pp. 322-3.

${ }^{84}$ The legislation then in force allowed females to perform underground jobs only from 1951 onwards.

${ }^{85}$ AAN, KC PZPR, 237/XXV-22, Biuletyn, 23/191 (1957), 27 April, p. 22. 
In parallel, women have not ceased pressing on the labour market. ${ }^{86}$ In 1955-6, those who had lost a job, as well as new applicants, were in search of labour. In spite of the discussions and postulates expressed in a number of milieus, the state eventually failed to provide attractive job quitting conditions for those women who wanted to give up work: it simply could not afford some ambitious solutions in the field of social policy ${ }^{87}$ Research done by the OBOP moreover pointed out that because of the existing obstacles hindering vocational or professional mobilisation, only a half of those willing to take up a job actually sought employment opportunities. ${ }^{88}$ What this means is that there were many more women ready to take up jobs than the state wanted, and could, employ. Every fourth non-working woman polled declared she was looking for a job (of which merely $44 \%$ were recorded with an employment office) ${ }^{89}$

The field research carried out by the Instytut Gospodarstwa Społecznego (Social Economy Institute) in 1957 showed that opening a new establishment in 'an economically backward area' resulted in considerable increase in the number of those willing to work. The possibility to get employed with such an enterprise caused that there were many job applications coming from women who had previously been dealing with household activities or worked irregularly. As a result, instead of dropping, the population of registered unemployed tended to increase $^{90}$ - a phenomenon that was termed 'female mobilisation spiral'.

To sum up, the conception was commonplace in the late 1950s that women's careers propped up the household budgets, in the first place, while female earnings played a secondary role for the family. As a consequence of these opinions came the view that where there is scarce work available, it is not owed to wives of 'high-earning' husbands. While the opinions with regard to legitimacy of employing

86 "There have been increasing numbers [of women] reporting their will to take up gainful work", a ministry note stated; AAN, MPiOS, 42, Notatka dla Kolegium Ministerstwa w sprawie zatrudnienia kobiet [Note to the Ministry's Board re. employment of women], p. 38.

${ }^{87}$ Jarska, 'Praca zawodowa robotnic', 281-302.

${ }^{88}$ Zygmunt Drozdek and Anna Preiss-Zajdowa, Stosunek kobiet do pracy zawodowej (Warsaw, 1962), 31.

${ }^{89}$ This would mean that there were some 200,000 women in search of employment at that time; ibidem, 30.

${ }^{90}$ Sobczak, Rynek pracy, 7. 
married women and mothers varied, they mostly had a central point in common: livelihood for the family. ${ }^{91}$ The voices opting for dismissing married women and mothers referred to the argument of other sources of upkeep available. The protests against the sacking of women, expressed by people of either sex, pointed to the economic necessity of employing female workers. The types of jobs that were a necessary complement, or outright the basis, of the home budget (such as work done by widows, abandoned mothers or wives of husbands incapable for work) were deemed justified, first of all. The arguments such as mothers needing to fulfil their educational role or satisfaction with one's work and career appeared in the background.

Like in the latter half of the 1940s, female joblessness was perceived stereotypically, its primary reason being identified - in the press or in private-office discussions among ministerial or Party officials - as insufficient skills or qualifications of female candidates seeking employment. ${ }^{92}$ And indeed, unskilled workers continued to form a definite majority of jobless women. A dozen-or-so per cent of women seeking jobs were categorised as 'sole breadwinners'; letters from blue-collar women workers accounted for a half of the complaints and requests received by the Labour and Wages Committee's Employment Department. In case of redundancy, "mostly those female workers who proved the least useful and of the lowest professional qualifications" tended to lose their jobs. ${ }^{93}$

Working women were, in any case, better educated than their male counterparts. At the threshold of the 1960s, 20 per cent of them had

${ }^{91}$ The diverse public opinions on female work seemingly continued for years. A 1974 OBOP research found that $41 \%$ polled agreed that "women ought to participate in professional life to the same degree as men do, whereas household and family duties should be shared in equal proportion amongst the spouses". A contrary view (woman to be wife and mother only) was supported by $36 \%$ respondents, whilst the model of career woman charged with household duties was chosen by $20 \%$. Most female respondents opted for the first model; Warsaw, Archiwum TNS OBOP, O sprawach kobiet - komunikat $z$ badań [On women's matters: a research communiqué], Sept. 1974, p. 1.

${ }^{92}$ Almost all press articles on female work published in Poland in the 1960s touched upon the skills issue.

${ }^{93}$ AAN, Komitet Pracy i Płac (hereinafter: KPiP), 6/49, Informacja dotycząca skarg i wniosków w KPiP za okres VIII-31 XII 1962 [Information re. complaints and requests at (i.e. submitted to) the Labour and Wages Committee as for Aug. to 31 Dec. 1962]. 
a higher or secondary education (the rate for males being 12.4\%). ${ }^{94}$ Men definitely prevailed among the worst-educated workers; as of 1958, over 1,450,000 of them did not have their primary education completed, which is to say that every third working male had virtually no education. The figure for women equalled 519,000 - meaning that every fourth female worker had no graduation certificate. ${ }^{95}$ It thus follows that the prevalence of men among unskilled workers was not based on the qualifications criterion but rather ensued from the sex and gender determinants.

On the other hand, the difficulties faced by women in the bluecollar market were interrelated with the culture-laden categorisation into 'female' and 'male' jobs. As a result, women's fitness for work in a factory tended to be lower; a woman would more often take up an industry-related job as a result of coincidence than one's conscious strivings. Women accounted merely for 13.2 per cent skilled workers in industry ${ }^{96}$ As few as 1.6 per cent of working women were regarded as 'professionals'. ${ }^{97}$ Young Polish women had their comprehensive education completed more often than young men, the proportion being reverse for vocational education - whereas the demand for qualified workers exceeded the demand for white-collars. As far as vocational training is concerned, girls mostly attended garment, textile, and food industry or economic schools, basically mastering their 'female' professional skills. This gender-related educational categorisation was reproduced in factories, where an almost absolute division into 'female' and 'male' working activities functioned. ${ }^{98}$

Thus, women performed their 'female' jobs - but such were the jobs they aspired for. According to a 1960 study done by OBOP, the respondents regarded 'typically female' jobs, such as teacher, clerk,

${ }^{94}$ AAN, KPiP, 8/18, Tezy na konferencję prasową w sprawie zatrudnienia kobiet [Theses for a press conference on female employment].

${ }^{95}$ Rocznik statystyczny pracy 1945-1968 (Warsaw, 1970), 267.

${ }^{96}$ KK CRZZ (ed.), Kobieta $w$ Polsce.

${ }^{97}$ ARZ, KK CRZZ, 113; Krystyna Wigura, 'Równouprawnienie w świetle Konstytucji i życia’, Przegląd Zwiazkowy, 3 (1960), 3.

${ }^{98}$ Although many women, who had been trained into the job in the time of Stalinist 'productivisation', still performed so-called 'male' or 'manly' jobs (as grinders, turners, and the like). Training of women for such professions began again in the early 1960s, but without ideological rationale behind the process yet; Jarska, 'Praca zawodowa robotnic', 331-3. 
shop assistant, or medical doctor, as suitable for them (incidentally, the names of these professions had by then assumed female grammatical forms). The polled women considered the jobs mechanical engineer and conductress 'rather inappropriate' for female worker. ${ }^{99}$ Their job-related preferences were also attested by their answers to the question concerning the desired job for their children: most of the respondents daydreamed that their daughters become physicians or teachers, and their sons - engineers. ${ }^{100}$

The answers to many questions in the 1960 poll were indicative of a low status of worker's activities among women. According to the respondents, women ought not to be a metal factory worker, the professions of grinding or lathe operator being likewise deemed by them inappropriate for females. A 'rather appropriate' one would be the post of a worker with a television assembly factory, which, sociologists suggested, could have to do with ignorance of the functions performed in such jobs - or, the belief that women would be particularly predisposed for jobs calling for precision work. The reluctance toward the types of work stereotypically deemed 'male' was quite evident, although there were many women at that time already performing some of such jobs. ${ }^{101}$ "Women ought not to do manufacturing jobs or drive vehicles, or perform other blue-collar jobs; otherwise, they lose their womanliness completely", a Warsaw Motorcycle Factory (female) worker stated. ${ }^{102}$ Worker jobs were perceived as not suitable for women also due to the conditions in which it was performed:

If she really has to work, the woman should have a clean, light, and easy job, one that would not expose her to any hazards, non-detrimental to her health, done in a female milieu or in an office environment. ${ }^{103}$

${ }^{99}$ Drozdek and Preiss-Zajdowa, Stosunek kobiet do pracy, 46-7.

100 A similar outcome is to be found in Warsaw, Archiwum TNS OBOP, 'Ankieta o ocenie zawodów i stanowisk', elabor. by Adam Sarapata, 21; based on a 1958 research conducted in Warsaw. The research has shown considerably divergent opinions about jobs and professions depending on the milieu, and no such discrepancies determined by the gender.

${ }_{101}$ Drozdek and Preiss-Zajdowa, Stosunek kobiet do pracy, 40.

102 Janina Waluk, 'Postawy kobiet wobec własnej pracy zawodowej', Studia Socjologiczne, iii, 3 (1963), 148-9.

${ }^{103}$ Halina Najduchowska, Pozycja społeczna starych robotników przemystu metalowego (fragmenty opracowanych badań) (Wrocław, Warsaw, and Cracow, 1965), 65. 
The conviction that women perform blue-collar work worse than men was rather widely disseminated and had an adverse impact on the situation of female blue-collars. Such conclusion was drawn by sociologists based on their poll of the crew of one Warsaw metal factory. ${ }^{104}$ One of the opinions they came across claimed that "a woman wouldn't make a worker anyway". ${ }^{105}$ There were women workers indeed, but their male counterparts would not ever consider them their peers.

As I have already mentioned, 'female' professions were the least adapted to the 'PRL-like', socialist labour market. The press reported that local national councils' employment sections abounded with job offers for welders, milling machine operators, turners and drivers, or unskilled labourers. This being the case, a man would not look for a job long; while he could make a choice, there were scarce offers for women. ${ }^{106}$ The prevalent economic development model did not foster creation of 'female' jobs, such as in commerce or services. The division into 'male'/'female' industrial sectors easily generated local unemployment. In Kraśnik-Fabryczny, a locality in Lublin region, the local metal factory was reluctant to employ women, whereas in Zambrów males were refused to get employed with the local textile plant. ${ }^{107}$

Lack of 'relevant' qualifications was often referred to as the reason for the particular difficulty for women in finding a job. As it turned out, however, such problems were also encountered by technical school graduates. ${ }^{108}$ The power of the stereotype prevailed over qualifications. The division based on the views on masculinity/femininity was evolving - the conductress job became popular, to give an example - but women were still not accepted for certain types of work. Characteristic arguments were posed, for instance, against the training of women as sailors. As a Sztandar Mtodych article stated,

${ }^{104}$ Jerzy Piotrowski (ed.), Struktura robotniczej załogi $w$ jednej z fabryk warszawskich (Warsaw, 1961), 14.

105 Ibidem, 168.

${ }^{106}$ Krystyna Kostrzewa, 'Przyczyny i skutki', Trybuna Ludu (1965), 22 Sept. (quoted after: AAN, Zbiór wycinków prasowych, 20/129).

107 Jarska, 'Praca zawodowa robotnic', 375; Andrzej Zawistowski, Kombinat. Dzieje Zambrowskich Zakładów Przemystu Bawetnianego - wielkiej inwestycji planu sześcioletniego (Warsaw and Białystok, 2009), 160.

108 AAN, OK FJN, 974, Informacja o aktualnym stanie kształcenia dziewcząt i kierunkach działania resortu $\mathrm{w}$ tym zakresie [Information on the current situation in the education of girls and the Ministry's related fields of action]. 
based on experts' opinions, the profession of sailor was inappropriate for women. ${ }^{109}$ In a psychologist's opinion, quoted by the author, "sailing and the job of sailor, in general, is contrary to woman's biological system and psyche". Moreover, this author undermined the girls' incentives for enrolling in a maritime school, stating that they have no idea about working on the sea and are only tempted by "exoticism and the veil of mysteriousness". And, she deemed women's work in the sea as irrelevant to 'the national economy'.

Similarly to the previous periods, in the 'minor stabilisation' years the general reluctance toward employing women continued. It was connected with the conviction that women are more costly, and still worse, employees. In the Warsaw metal factory researched by sociologists, the director, foremen and brigade leaders did not consider women 'full-fledged workers' ${ }^{110}$ The enterprises' aversion to recruiting or employing women appeared due to 'objective reasons': higher sick-absenteeism, lower qualifications, frequent maternity leaves. 111 "There is a psychosis about women using the leave option too frequently", a (female) trade union activist observed. At a meeting where employment of women was discussed, enterprise directors complained about the necessity to transfer pregnant women to lighter work, "unsteady professional interests among women", "the difficulty in arranging women for three-shift labour system, owing to their family duties", "reluctance of women to take up responsible work." In a word, "there are as many problems in the establishment as there are women."112

The 'objective' premises for the unwillingness to employ women turned out to be hard to verify. The studies of absenteeism, for instance, gave rather ambiguous results; according to some of them, female workers took their days-off much more frequently, while men prevailed as far as unauthorised absence was concerned. Other research did not prove that there would be any relation between the percentage of women in the total number of employed in a given industrial branch

${ }^{109}$ Ludmiła Toporowicz, 'To nie dla kobiet', Sztandar Młodych (1965), 9 Jan. (quoted after: AAN, Zbiór wycinków prasowych, 20/129).

110 Piotrowski (ed.), Struktura robotniczej załogi, 24.

111 AAN, KPiP, 8/18, Tezy na konferencję.

112 ARZ, KK CRZZ, 103, Notatka służbowa [Memorandum], 12 Sept. 1964, pp. 183-4. 
and both types of absenteeism (sick leaves and unauthorised). ${ }^{113}$ Moreover, establishments incurred much higher losses owing to their employees' falling ill than due to maternities. Days-off due to maternity appeared with a mere 6 per cent of employed women per annum, "whereas the troubles of workplace administrations and the opinions on maternity leaves are repeatedly aggrandised". ${ }^{114}$

All the managers in the Warsaw metal factory agreed that "poorer output' and 'high absenteeism' were characteristic of female workers, they themselves being to blame. ${ }^{115}$ Females indeed achieved much worse results in terms of production standards, whereas the research outcome was not quite clear in case of 'defective work'. Absenteeism of females did not, in general, much exceed the one of males. Women workers had almost no unjustified absence and abused leave options to a lesser extent. ${ }^{116}$

The convictions about women being worse-performing employees can be related to the fact that their work was perceived as 'additional'. The primary identity of woman was to be based on her role in and for the family and household. Professional activity would add to these basics, forced by the economic necessity - which, in any case, was also rooted in the needs of the family. In case a woman would not work to contribute extra money to the household budget (or to provide for her family), the work she did was perceived in terms of 'will and pleasure'. These gender-related conditions for the disinclination for employing women are key for understanding their disadvantaged position in the professional environment and their joblessness. Hence, the authorities explained to themselves that unemployment was not

113 Wiesław Caban, Absencja w przemyśle włókienniczym na przykładzie Zakładów Przemystu Bawetnianego im. F. Dzierżyńskiego w Łodzi (Lodz, 1963), 19-20.

114 Irena Andrzejewska and Krystyna Wrochno (eds.), Z doświadczeń komisji kobiet pracujacych zwiazków zawodowych (Warsaw, 1964), 87-8. The research done by Adam Kurzynowski showed that the proportion of female workers on maternity leave in January to June 1960 equalled 1\%-4\%; see idem, Ciagłość pracy a macierzyństwo (Warsaw, 1967), 36. Of the working mothers, $49 \%$ had one child, 35\% - two, and $11.3 \%$ - three children.

115 Piotrowski (ed.), Struktura robotniczej załogi, 153-4.

${ }^{116}$ Ibidem, 162-4. Interestingly, the factory's managerial team reproached the female workers for taking advantage of leaves: "it happens that a woman helps festering her finger wound, for that matter, in order to acquire extension of her sick leave, and then she deals with some trading or does laundering at home"; ibidem, 134. 
completely a real problem since it "is not implied by the systemic or structural reasons but [it has appeared] resulting from low wages, this being the reason that the employed having a family cannot earn enough to subsist them."117

VI

\section{COMBATING UNEMPLOYMENT}

The specific perception of woman in the context of professional activity, rooted in gender stereotypes, also shaped the social policies which invariably set its sights on eliminating unemployment. The unemployment combating instruments in the latter half of the 1940s and in W. Gomułka's time were similar; yet, those who created those policies were aware of the cultural determinants of unemployment only to a slight extent.

The years 1947-50 saw the launch and unfolding of the so-called Employment Action ('AZ' - Akcja Zatrudnienia), as part of which training was provided to women and working cooperatives formed in order to offer employment to the trained women. ${ }^{118}$ The project was meant to extend to women

whose material situation was particularly burdensome (resulting from the war and occupation), or to some of those who have not enjoyed appropriate conditions of [i.e. for] doing an industry work. ${ }^{119}$

Criteria were assumed according to which women aged thirty-five minimum and with no professional qualifications were referred for training, along with widows and those who for family-related reasons could not migrate to other localities. ${ }^{120}$

Within the three years of the action, most (more than 18,500) training course delegates found employment with clothing manufacture.

117 AAN, MPiOS, 42, Notatka stenograficzna, p. 71.

118 Zofia Chyra-Rolicz, Spótdzielczość pracy w aktywizacji zawodowej kobiet (Warsaw, 1980). AAN, MPiOS, 562, Instrukcja w sprawie aktywizacji zatrudnienia [Instruction re. the mobilisation of employment], 10 Oct. 1947.

${ }^{119}$ AAN, MPiOS, 561, Sprawozdanie $z$ akcji gospodarczego usamodzielnienia niezatrudnionych kobiet $\mathrm{w}$ okresie 1947-50 r. [Report on the action to render unemployed women economically independent in 1947 to 1950], p. 2.

${ }^{120}$ Ibidem, Pismo okólne MPiOS Departament Zatrudnienia [Circular letter, MPiOS, Employment Department], 28 Feb. 1950, p. 52. 
They were moreover trained for typically cooperative and artisanal professions, such as cap-making, gastronomy, bag bonding, cutting and sewing, haberdashery, slipper manufacturing, brush-making, and the like, as well as typing and nursing. ${ }^{121}$ The trainings scheduled for the years 1948-9 specified a scarce number of professions not deemed typically female at the time (e.g. house painter or installation electrician). ${ }^{122}$

In spite of a number of institutions involved and considerable money allocated to the action, it turned out to be not quite efficient, and partly misbegotten. A problem of importance was scarcity of raw materials, which prevented the opening or proper functioning of some cooperatives, and lack of market for sale of their products. Production turned out unprofitable due to low productivity. ${ }^{123}$ Cooperatives consumed and absorbed the money, and although they fulfilled their primary goal, their activities were often preposterous, owing to the economic incapacity. What is more, at the outset of the Action, some of the trained women remained jobless, due to a variety of difficulties. ${ }^{124}$

The final outcome of the Action, which was completed by the end of 1950, were not significant, taking into account the scale of female employment. In 1950, a total of 206 cooperatives set up as part of the Action employed 25,000 women. A definite majority of them found employment with 127 clothing-manufacture cooperatives. The remaining dozen-or-so sectors had a few cooperatives each. ${ }^{125}$

The Action under discussion reflected the approach of public institutions to the unemployment issue, characteristic of the period.

121 AAN, KC PPR, MF 2451/5, Szkolenie zawodowe kobiet i współdziałanie $\mathrm{w}$ akcji zatrudnienia [Vocational training of women and collaboration in the employment action], pp. 72-3.

${ }_{122}$ Ibidem, Program pracy [Zarządu Głównego Społeczno-Obywatelskiej Ligi Kobiet] na lata 1948/49 [Work programme (of the Central Board of the Social-Civic League of Women) for the years 1948-9], p. 76.

123 AAN, KC PPR, 295/XI-92, Notatka [A note], March 1948, p. 2.

${ }^{124}$ Ibidem, Sprawozdanie z akcji usamodzielnienia gospodarczego kobiet bezrobotnych prowadzonego przez LK [Report on the action to render unemployed women economically independent, run by the League of Women], pp. 7-8.

${ }^{125}$ AAN, MPiOS, 561, Wykaz branż Spółdzielni Pracy zorganizowanych w ramach akcji AZ w latach 1947-1950 [A list of Labour Cooperative sectors organised as part of the 'AZ' action in 1947-50], p. 76; ibidem, Wykaz ilościowy spółdzielni oraz kredytów według województw [A quantitative breakdown of cooperatives and credits, by voivodeship], p. 77. 
The measures applied were temporary. Female activists and ministry advisors perceived female unemployment as an aftermath of the war and of the loss of breadwinners - a problem that followed from a unique, even if extreme, though temporary situation. The training and cooperative employment offered to women was a kind of social assistance. The difficulties women faced looking for a job were considered objective: no skills; low mobility; no 'appropriate' job positions available. Even though there was awareness that discrimination with regard to gender existed, no attempts were made to combat it. The vocational training profile did not radically diverge from the professions deemed 'female'; as Małgorzata Fidelis noted, there was no reference made in the context of the 'AZ' action to gender equality. 126

Again, the authorities attempted to solve the problem of unemployment incrementing from 1955 on. Local national councils interceded for female 'sole breadwinners' to be offered employment directly by establishments. Attempts were made at establishing new labour cooperatives and involving women for seasonal employment. ${ }^{127}$ All these means and measures were expedients, though. The Ministry of Labour and Social Care sought for long-term methods to 'eliminate the surpluses', envisioning that the difficulties faced by women in finding a job would be increasing. A concept was proposed to subordinate the plan for deployment of new industrial establishments to the unemployment problem. Another idea of how to provide employment to female jobseekers was to set up cooperatives and develop cottage industry. It was envisaged that the Central Cooperative Movement Association would offer jobs to 35,000 women in 1956 alone, in sectors such as toy and souvenir manufacture, plaiting, linen production, embroidery, and knitting. ${ }^{128}$ Cottage industry was to offer jobs to 24,000 females; work of this sort was primarily meant to be a form of social assistance. ${ }^{129}$ The idea to develop 'female' cooperatives bringing together small craft initiatives resembled the 'AZ' action

126 Fidelis, Women, Communism, 51.

127 AAN, PKPG, 3282, Notatka w sprawie zatrudnienia nadwyżek kobiet [Note re. employment of excessive numbers of females], Dec. 1955, pp. 113-14.

128 Ibidem, pp. 115-16.

${ }^{129}$ AAN, PKPG, 3282, Analiza i wnioski podkomisji powołanej przez Komisję Rządową [Analysis and conclusions of the subcommittee appointed by the Governmental Committee], p. 39. 
from 1947-50. Furthermore, the option for women to be employed on a part-time basis was also taken into consideration. ${ }^{130}$

On the other hand, the idea was considered to increase allowances for families with more than two kids, "so that women burdened with a large family, and especially with small children, not have to do gainful work, to the detriment of bringing up their kids". An openly declared objective of this move was to diminish the number of women seeking jobs. ${ }^{131}$ The proposal to reconsider the "working time for females" had a similar undertone to it.

As a result, the planned female employment policy assumptions were ambivalent in respect of their attitude to professional work. Methods were sought, on the one hand, to increase the employment, and on the other, to discourage from taking up a job. A paper on female employment delivered at a Ministry of Labour and Social Care Board meeting remarked that "we shall not be capable of inhibiting the women's push for employment until we are capable of increasing the salaries for men". Since this goal was unrealistic, the objective of an employment policy ought to be to provide work opportunities to all job-seeking women whilst preventing any further increase in the scale of female employment. Higher family allowances were meant to discourage women from taking up employment. ${ }^{132}$ Such a view is interpretable in the context of the period's slogans demanding that women 'return home', but is also decipherable in the context of the economy's needs. "We need female labour no more", decision-makers seemed to be claiming. They deemed working mothers particularly redundant, as they believed their gainful work overburdened the state. Leon Chajn, undersecretary of state with the MPiOS, directly voiced such stance at a MPiOS Board meeting, arguing that the overall economic conditions enforced reduced employment of women. While

${ }^{130}$ AAN, MPiOS, 42, Notatka dla Kolegium Ministerstwa w sprawie zatrudnienia kobiet [Note to the Ministry Board re. employment of women], pp. 42-4.

${ }^{131}$ Ibidem, pp. 44-5. Women quitting their gainful jobs would produce vacancies, thus adding to decreased unemployment. ARZ, Wydział Ekonomiczny CRZZ, 13a, Wnioski zespołu dotyczące rozładowania nadwyżek siły roboczej [The Team’s conclusions regarding the discharge of workforce surpluses], 1956.

132 AAN, MPiOS, 42, Notatka stenograficzna, pp. 68-9. An increase in family allowances for "poorer-paid large families [i.e. those with four or more kids]" was envisioned by the resolution of 7th Plenum of the Central Committee of PZPR of July 1956; see Nowe Drogi, 7-8 (1956), 207. 
considering vocational mobilisation of females an achievement of the communist system, he pointed out to the need to revise the existing policies. Chajn opted for creating a situation where wives of working men would not take up jobs at all, arguing that a large number of working women actually do not work (as they permanently go on leaves), suffer and feel pain, earning rather a little. Chajn moreover suggested that young ladies who work to "earn extra money for their own needs" be fired, and that married women be treated otherwise than single ones. ${ }^{133}$ A communist activist argued that too many mothers had taken up jobs, thus causing economic and social problems: those women were not, to her mind, full-value workers, and taking jobs by them had an adverse bearing on the lives of their families and upbringing of their children. ${ }^{134}$ Another activist suggested that maternity leave should be extended so that mothers of small children could work for a possibly short period. According to most of the debaters, the numbers of employed mothers, married women, or - in the extreme version - women in general should be restricted. Decision-makers shared the prevalent public opinions in this respect. How such a policy would be implemented remained a problem.

Finally, however, the designed policy could not aim at reduced employment among women. ${ }^{135}$ Regardless of the views on female employment, it appeared clear that women's professional mobilisation was not to be withheld. As a result of these contradictory strivings, instruments to increase employment were created - only to manage the unemployment, though. The Council of Ministers' resolution of August 1956 authorised the local national councils to make recommendations to workplace managers in regard of "transferring men from jobs suitable for women to other jobs". The vacancies thus created were to be "filled with women seeking for jobs, the only breadwinners for their families in the first place". Several ministries (Municipal Economy, Railways, Communications, Machine-Building Industry, Light Industry, Internal Trade, and other) were recommended to determine the "breakdowns of job positions for which women should be employed in the first place."136 That heavy and mining

133 AAN, MPiOS, 42, Notatka stenograficzna, pp. 73-4.

${ }^{134}$ Anna Wolf, ‘Tym razem w Sejmie', Kobieta $i$ Życie, 33 (1956), 2.

135 AAN, MPiOS, 42, Notatka stenograficzna, p. 86.

${ }^{136}$ Monitor Polski, 78 (1956), item 953, ‘Uchwała nr 521 Rady Ministrów z dnia 17 VIII 1956 w sprawie zasad zatrudniania pracowników w uspołecznionych 
industries are missing among those sectors is significant: this made an essential difference against the policy of 'productivisation' in the first half of the 1950s. Efforts were made, with use of administrative methods, to increase female employment (primarily with regards to those who 'had' to work) and fight unemployment, without crossing the safe limits of 'female' and 'male' professions.

The strategy of combating joblessness slightly changed in the 1960s. In 1961 and 1962, the Labour and Wages Committee (created in 1960 to replace the Ministry of Labour and Social Care) issued its "guidelines regarding increased employment of women" to be binding in the subsequent years. In the areas with workforce deficits percentage rates of female employment were to be set for individual industrial branches and establishments. Following a series of inspections, job positions potentially available for women were determined for the largest workplaces. Training and transfer of women to positions occupied by men were recommended. ${ }^{137}$ A year later, the effect of these guidelines was extended, including by ordering the individual ministries to issue relevant instructions. The planning of gender proportions was to be valid for vocational school students as well. ${ }^{138}$ Attempts were made to organise vocational courses and train female workers for professions deemed male. This policy did not eliminate any of the basic problems, nor did it contribute to a qualitative change in women's employment. Joblessness was not eliminated, either.

\section{VII \\ CONCLUSION}

In the light of female unemployment research, the influence of gender on the labour market in the post-war communist Poland is demonstrable - in terms of engaging and employing women and the categorisation into 'male' and 'female' jobs and professions.

zakładach pracy' [Resolution no. 521 of the Council of Ministers of 17 August 1956 on the principles of employment with socialist workplaces].

137 AAN, KPiP, 8/18, Wytyczne Przewodniczącego KPiP z dnia 5 kwietnia $1961 \mathrm{r}$. w sprawie zwiększenia zatrudnienia kobiet [Guidelines of the Chairman of the Labour and Wages Committee of 5 April 1961 re. increased employment for females].

138 Ibidem, Wytyczne Przewodniczącego KPiP z dnia 31 marca 1962 r. w sprawie zwiększenia stanu zatrudnienia kobiet [Guidelines of the Chairman of the Labour and Wages Committee of 31 March 1962 re. increased female employment statistics]. 
Women were primarily perceived in the context of family life: as married women, mothers, maidens, widows, single mothers. Their status determined the public expectations with regards to taking gainful work. Family discerning between the duties of a male 'breadwinner' and a female housekeeper was continually the dominant family model and (unattainable) ideal. ${ }^{139}$ The man's work needed no legitimisation. Economic needs gave grounds for gainful activities of women; in case such needs were (subjectively) not the case, women were 'suspected' of working for some 'trifling' reasons (out of boredom or in order to satisfy their illegitimate consumption needs). These non-material reasons were contrary to the commonplace idea of social justice. In the first years after the war, women had to work as they were 'single' - temporarily, it was believed. In periods of labour deficit, 'wives of high-earning husbands' were dismissed. In spite of the official ideology, proclaiming emancipation of women through gainful work, such views were shared by people who wielded power and shaped the social policy and public opinion. Such beliefs were subject to a very slow evolution, in spite of professional mobilisation of women, including married women and mothers, the strengthening of was irreversible, which had become obvious in the first half of the 1950s.

Women's abilities to work were also perceived through the prism of their identity as married women and mothers. Woman, particularly if a worker, was - as it were, by definition - a lower-quality employee as her professional role had to be subordinated to her family role. This caused that the issue of maternity and other leaves tended to be exaggerated. As a result, disinclination for employing women prevailed. Those women who cared about their work had to persuade their employer and environment that they could cope with combining the roles, and to give grounds for their professional activity by referring to the needs of their families. Female joblessness was invariably perceived in a stereotypical fashion. The dominant ideas about female identity caused that jobless but skilled women generally tended to be neglected. ${ }^{140}$

${ }^{139}$ It has to be emphasised that the degree of rooting of such a model in the mentality was milieu-dependent: it was represented the strongest among skilled workers and to a lesser degree in worker milieus of rural origin, lesser still among the intelligentsia.

${ }^{140}$ As Wendy Z. Goldman observed, based on her analysis of female unemployment in the USSR in the 1920s, joblessness was only associated with qualifications, neglecting the crucial role of sex/gender; see eadem, Women at the Gates, 18. 
The persistence of such views during the first decades of post-war communist Poland also testifies to a very limited influence of the propaganda and the 'productivisation' policy targeted at women in the course of the Six-Year Plan. While these factors did contribute to a rapid and irreversible increase in female employment, they did not help modify the definitions of male and female roles. In the 'thaw' period it became apparent that a host of decision-makers shared such stereotypical views.

The division into professions deemed appropriate or suitable for males or females posed certain hard-to-cross barriers. Employment offices defined workplaces in terms of their gender profile; even if qualified for a job that was not conformant to these ideas, the jobseeker did not have her professional life facilitated.

The situation of women in the labour market was also deteriorated by some other factors that grew relevant in combination with the cultural aspect. First, decisive for elimination of unemployment was the absorptive capacity of the labour market; in the periods of considerable workforce deficit, particularly the years 1950-3, industries abounded with job offers for either sex. Second, above all, some 'female' jobs (performed by women and considered appropriate for females) did not fit the labour market which was invariably, and above all, in need of qualified workers - whilst among the industrial branches and sectors 'male' jobs prevailed. Such were the consequences of the assumed economic development model that stressed the development of industry at the expense of services. Thirdly, undermechanisation of certain industrial activities caused that their performance required considerable physical effort, which in turn hindered the opting for jobs of this sort by female workers. ${ }^{141}$

Unemployment among women was successfully eliminated in the 1970s, thanks to the social policies applied. Although it seems that the basic determinants of gender's influence on the labour market were not considerably transformed at that time, this particular issue would call for further research.

trans. Tristan Korecki

${ }^{141}$ Let me remark that the notion of 'hard work' was gendered, to an extent - as attested, i.a., by the fact that a number of burdensome and really hard and demanding types of jobs in textile industry were deemed 'female' and 'light'. 